\title{
AUTOMATED DESIGN OF VEHICLE SILHOUETTES USING GENETIC ALGORITHMS AND STATISTICAL ANALYSIS
}

\section{DAVID ŠKAROUPKA}

Institute of Machine Design, Brno University of Technology, E-mail: yskaro03@stud.fme.vutbr.cz

\section{ČENĚK ŠANDERA}

Institute of Mathematics, Brno University of Technology, E-mail: ysande01@stud.fme.vutbr.cz

\section{SHRNUTÍ}

Tento článek popisuje metodu automatického návrhu siluety vozu. V průběhu historie vzniklo mnoho automobilů jejichž rysy jsou do značné míry podobné. Tyto rysy (siluety) můžeme extrahovat pomocí statistické metody analýzy hlavních komponent a použít je pro návrh nové siluety, která je dále optimalizována pomocí genetických algoritmů. Proces optimalizace zohledňuje zadané fyzikální parametry jako je objem prostoru pro motor, zavazadla a pasažéry. Výsledek produkovaný algoritmem pak slouží jako inspirace pro člověka-designéra a může být zobecněn na vybraný typ produktu.

KLICCOOVÁ SLOVA: NÁVRH AUTOMOBILŮ, STYLING AUTOMOBILU், PRODUKTOVÝ DESIGN, STYLING, PCA (ANALÝZA HLAVNÍCH KOMPONENT), GENETICKÉ ALGORITMY, VÝVOJ A NÁVRH PRODUKTU

\section{ABSTRACT}

This paper describes a method for the automatic design of vehicle silhouettes. Over the years many different vehicles have been created, but most of them share similar features. We can extract these features through statistical analysis (principal component analysis) and use them in creating the shape of a vehicle's silhouette. To produce the new original silhouettes we utilize an optimization method (a genetic algorithm) which fits the new silhouette to the prescribed physical conditions, e.g. space for the engine, space for the passengers etc. This algorithm serves as a source of inspiration for human designers and can be generalized to produce many kinds of products.

KEYWORDS: VEHICLE DESIGN, VEHICLE STYLING, PRODUCT DESIGN, STYLING, PCA (PRINCIPAL COMPONENT ANALYSIS), GENETIC ALGORITHMS, DESIGN AND PRODUCT DEVELOPMENT

\section{INTRODUCTION AND PROBLEM}

\section{STATEMENT}

This paper focuses on the use of computational mathematics to create a valuable contribution to vehicle design and styling. The strong design potential of the computer was considered with interest in the 60s (Alexander, 1964). Alexander observes that although many design tasks have a lot of variables (product requirements), there is only one ideal solution. The quantity of the variables (product requirements) is a problem that a human designer overcomes through personal experience and habits. Of course, it is not feasible to check all the possibilities, and this is why the best solution will never be found. Therefore the author suggests using a computer in a specific way. It is clear that the role of the computer is important, and this was true even in 60 s. It is not a question of whether to use a computer or not. The point of Alexander's ideas rests in the question of what to use it for. He noted that there are some common tasks that a computer is ideal at dealing with, but nobody uses it.

Problems like these exist in computational aesthetics, and this topic still gives rise to animated discussions about aesthetics and its possible computability. In the 70s Stiny and Gips (Stiny et al., 1972) brought Shape Grammars into the discussion. They used a logical structure of rules to define how new artwork, such as a painting or sculpture will look. Stiny and Gips have many followers. Seth Orsborn et al. are known in the field of vehicle design and styling. Firstly they defined how principal component analysis (PCA) can be used for evaluating product shapes and the relationships between them (Orsborn et al., 2008, Identifying Product Shape Relationships Using Principal Component Analysis). Later they employed the shape grammars to build 
orthogonal views of vehicles (Orsborn et al., 2008, Automating the Creation of Shape Grammar Rules) and they also developed a method for quantifying the customer's aesthetic form preference (Orsborn et al., 2009). The computer as a tool for designers can be used in the sense of Computer Aided Styling (CAS), for example 3D applications in combination with marketing research tools (Lin-Lin et al., 2007), or enhancing 3D modeling using tools for extracting curves from sketches (Kara et al., 2006) (Lin et al., 2004). Thus the computer can contribute to creating an idea or new design.

This paper provides a contribution to the realization of the idea. Every new product has many predecessors and the designer makes choices as to which features of the predecessors will influence his new product. It is not possible for the human designer to extract all these features in an exact way, even if the number of the chosen samples (inspirations) is significantly reduced. Our main goal, presented in this paper, is to develop a methodology for the exact consideration of inspirations for a new design and to verify it with a working example.

\section{ANALYSIS OF THE STATED PROBLEM}

The design process for a new product involves taking the product's history into account. The designer faces the problem of selecting suitable features of its predecessor and integrating them into the new composition. We propose a novel method, based on principal component analysis and genetic algorithms, for an algorithmic treatment of such tasks. A proper understanding of the algorithm requires us to state our interpretation of the design process and define the opportunities for its computational improvement. For the sake of simplicity, we describe the design process as a sequence of objectives, which we will also use as a basis for prescribing suitable conditions of the algorithm.

\subsection{DESIGN PROCESS WITHOUT ANY ALGORITHM:}

1. A human designer considers his inspiration (consciously or not) and defines the vehicle shape by free hand (applying some features of predecessors into the new design).

2. The shape is fitted to the correct dimensions with respect to the product's architecture (Chin, 2004). The architecture can be represented by simple shapes defining its volumes and spaces (a package).

3. Design finishing using an arbitrary method.

\subsection{DESIGN PROCESS INCLUDING AN ALGORITHM:}

1. Defining the product (a package) architecture. Collecting samples of the product's predecessors.

2. Running the algorithm and determining a new silhouette in the correct scale.

3. Design finishing using an arbitrary method.

\subsection{VEHICLE SILHOUETTES, EXTRACTING OF A SILHOUETTE:}

The majority of a vehicle's visual aspects can be seen from a side view, where the silhouette plays the key role. Dealing only with one silhouette, represented by a curve, reduces the complex design task to a simple form and allows us to start to develop an effective algorithm.

The design style of vehicles can be divided into two basic categories, evolutionary and revolutionary (Tumminelli, 2006). Those two kinds can by ramified by different approaches as rational or emotional. The problem of classifying the design style is in fact more complex, but for this paper it is important to describe only evolutionary and revolutionary kinds.

- Evolutionary design: A designer considers obligatory needs (utility, ergonomics, economy, ecology, aesthetic, etc.) and aims to achieve an original and aesthetically well balanced product. Every new design carefully adapts features of all its predecessors in history. For an example see Figure 1.
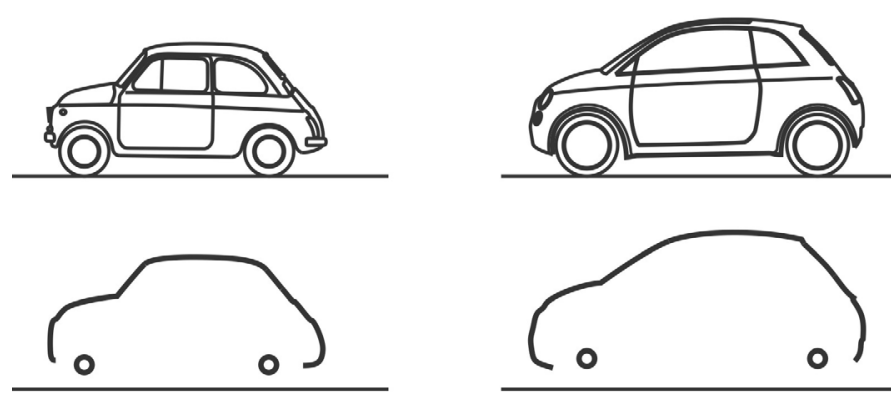

FIGURE 1: Example of evolutionary design. OBRÁZEK 1: Př́klad evolučního návrhu.

- Revolutionary design: A designer also considers all the needs relating to the essence of the product. A deep rethinking can give rise to fundamental innovations and originality of design. The predecessors are chosen arbitrarily by a designer. For an example see Figure 2 .
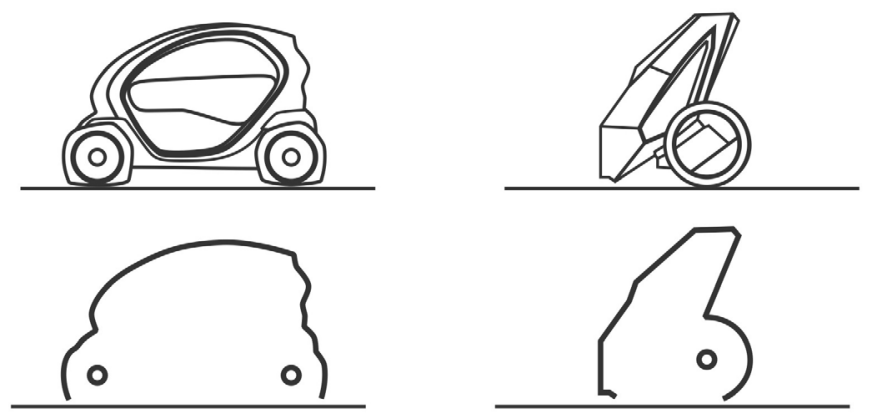

FIGURE 2: Example of revolutionary design. OBRÁZEK 2: Př́klad revolučního návrhu. 


\section{STATISTICAL ANALYSIS OF SILHOUETTE CURVES}

Several methods can be used to analytically describe a plane curve. The popular methods include description by Bezier curves, by splines or by a series of space coordinates connected by straight lines. We approximate our curves by the continuous connection of linear vectors (see the example in Figure 3 ), where each vector contains two real-valued components (increments on the perpendicular axis of the plane). For instance, if we have one hundred vectors we have two hundred real numbers which define a curve in the plane. From the statistical point of view, these points form a random vector with two hundred dimensions. The components of the random vector are not independent, but they have some strong correlation between each other. The highest correlation is between components which define close plane vectors of the curve.
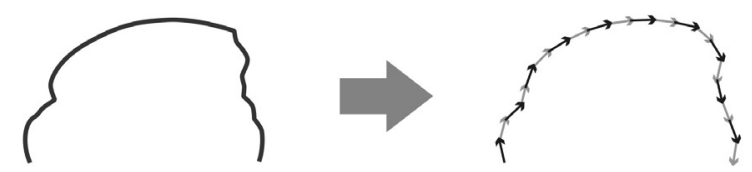

FIGURE 3: Example of used method of statistical analysis of vehicle silhoutte.

OBRÁZEK 3: Př́iklad použité metody statistické analýzy siluety vozidla.

Not all the possible curves in the plane look like vehicle silhouettes. The key idea is to define a few real vehicle silhouettes and find correlations between their vector descriptions. Afterwards, the subclass of all the curves which have similar correlations to real vehicles is considered to be the set of all the possible vehicle designs.

Principal component analysis (PCA) is a convenient statistical method for describing a set of vectors with given correlations. It identifies linear combinations of the vector components where the obtained outcomes have the highest variance. The obtained linear combinations are called principal components and they are, in fact, transformations of the initial space into the space with the new basis. In general, the method gives the same number of components as the initial space has, but most of them have very small variance and therefore they can be omitted without substantial loss of information. Each of these principal components is independent and uncorrelated with each other. This lets us set the most significant components to arbitrary values, neglecting the unimportant components, and by inverse transformation obtain a vector from the initial space with similar correlations to the original elements.
Mathematically speaking, the linear combinations are represented by the eigenvectors of the covariance matrix and the variances of their transformations are their related eigenvalues.

Let us denote a matrix of the original data as $X$, where its rows are particular elements $x_{i}$ and columns are their components. The vector $\mu_{\mathrm{X}}$ represents a mean of each column in matrix $X$.

Matrix $B=X-\mu_{\mathrm{x}}$ is then a normalized data matrix and $v_{i}$ are its eigenvectors with corresponding eigenvalues $\lambda_{i}$. If the eigenvalue $\lambda_{i}$ is greater than 1 , we consider the eigenvector $v_{i}$ to be the significant principle component. Matrix $W$ composed of the significant components is the transformation matrix and its transposed matrix $W^{T}$ represents the inverse transformation.

Now, if we have some element $x_{\text {orig }}$ from the original space, we can transform it into the new space by $x_{\text {transf }}=\left(x_{\text {orig }}-\mu_{X}\right) \cdot W$. Conversely, an element $y_{\text {transf }}$ from the principal component space can be transformed to the original space by $y_{\text {orig }}=y_{\text {transf }} \cdot W^{T}+\mu_{X}$. For more details about the PCA method see (Johnson, 2007).

\subsection{ALGORITHM FOR IDENTIFYING AN APPROPRIATE VEHICLE SILHOUETTE}

The subspace of all curves which look like vehicle silhouettes is described by several real numbers related to the principal components. Now, the main question is how to choose a curve which satisfies our prescribed constraints. The constraints include smoothness of the curve, adhering to required dimensions, etc. Most of these requirements have a strong nonlinear character and therefore it is nearly impossible to obtain an accurate solution. A class of algorithms capable of giving sufficiently good solutions are soft computing methods. These methods are usually based on some heuristics and artificial intelligence approaches. We selected a genetic algorithm designed for searching for numerical vectors with predefined properties.

The main idea of the genetic algorithms is based on Charles Darwin's theory of evolution. This theory states that a population of some species is adapted to its environment by producing new better individuals. The more adapted the parents are, the better offspring they can produce. Thus the genetic algorithms try to mimic this evolutionary process and use it for solving computationally complex problems. At the beginning, the algorithm creates a set of random candidate solutions (population of species), and by choosing a pair of high quality individuals (parents) it produces new solutions (offspring). If the new offspring is better than some individual in the current population, then the old one is deleted and replaced by this newly produced solution. The algorithm repeatedly produces new individuals and thereby the population improves with each iteration. The final solution is the best individual discovered during the whole algorithm run. The genetic algorithms have many variations and for a more precise description see (Yang, 2008). 


\subsection{UTILIZED ALGORITHM}

The initial step of the whole procedure is to create a few vehicle silhouettes and compute all the necessary parameters using the PCA method. The set of all the silhouettes will serve as a database for new vehicle designs. Our implementation approximates each of these silhouettes with one hundred real vectors (similar to Figure 3 ) and the sequence $x_{i}$ is obtained from the components of these vectors. Then the matrix $X$ is constructed by putting all the vectors $x_{i}$ into separate rows. Finally, the matrix $W$ of $n$ principal components is computed using a PCA algorithm for the created matrix $X$.

Now the aim of the algorithm is to find the curve which is as close as possible to the predefined package and which has similar properties to the cars in the database. This can be achieved by the aforementioned genetic algorithm used in the space of principal components. At the beginning, a few initial curves are randomly created and then the new curves are produced by one-point genetic crossover (combination of random parts of two selected curves) (Yang, 2008). The mutation is performed with the probability at 0.05 such that one of the principal components is randomly changed to a new value.

All these operations are carried out in the space of principal components, i.e. the curve is represented only by $n$ numbers and for verifying its quality it is necessary to transform it back to the initial space. The transformed curve is obtained by multiplying the principal components by $W^{T}$ and its fitness can be computed by comparison with the defined package. We use the Hausdorff metric for quantifying the proximity between the curve and the package, defined as a maximum of Euclidean distances between each point of the curve and the package. The other important conditions, laid down on the curve, are that none of its points can be inside the package (see Figure 4) and also its smoothness should be sufficiently low (minimum number of points of inflection). The objective is therefore to minimize a linear combination of the Hausdorff distance, the number of points inside the package and the number of points of inflection. The algorithm ends when the quality of the best curve is satisfactory or when a predefined number of iterations is reached.

The following pseudocode describes the algorithm:

$X=$ matrix of approximated silhouettes (one row is one silhouette).

$W=$ computed matrix of principal components by PCA algorithm from $X$.

$n=$ the number of the principal components

population $=$ set of 70 randomly created real vectors of length $n$ while termination is not met

parents $=$ select two vectors from the population

offspring $=$ crossover the parents and produce one new vector with low probability mutate the offspring new_silhouette $=W^{T}$ * offspring compute the fitness of the new_silhouette (proximity + inside points + smoothness) if the fitness is better than some other member in the population, then replace it.

End while

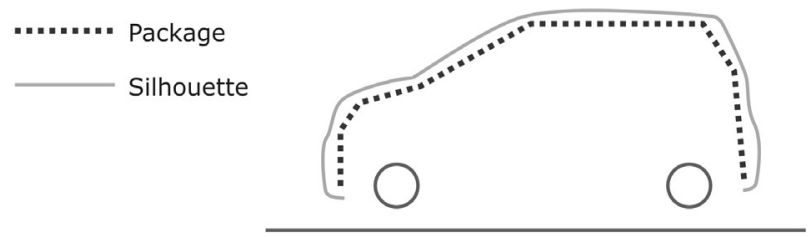

FIGURE 4: Example of generated silhoutte around defined package OBRÁZEK 4: Př́klad vygenerované siluety kolem určené obálky

\section{EXPERIMENTS}

We conducted several experiments belonging to two categories with different objectives. The first category contains experiments on the evolutionary method of design, and the second category on the revolutionary method. The evolutionary experiments compared two different brands of standard vehicles on the same package. We took ten samples from both brands and let the algorithm evolve a new design for each brand separately. Unfortunately, the obtained results did not meet our expectations. They did look different for each brand, but did not have the appropriate quality of a standard vehicle design. The results of experiments from this category are not intended to cover the history of the predecessors, but rather only some chosen samples.

The experiments from this category can briefly be described as follows:

- We take ten different vehicles into account (chosen silhouettes) and these vehicles form a group of the initial patterns for our experiment.

- We create a package (the physical conditions) and ran the algorithm (PCA + genetic algorithm).

- The obtained curve is finished using standard designing procedure.

\section{DESCRIPTION:}

The first step of the algorithm is to choose the set of predecessors and convert them to the same scale and form suitable for the algorithm. The chosen samples are shown in Figure 5; these vehicles are mainly experimental and innovative cars developed in the recent past. 


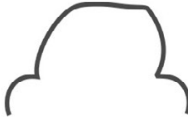

sample 1

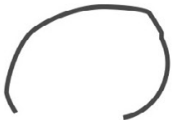

sample 6

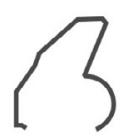

sample 2

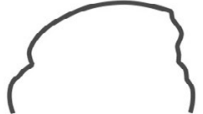

sample 7

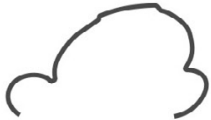

sample 3

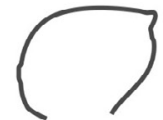

sample 8
15

sample 4<smiles>C1CCCCCCC1</smiles>

sample 9
13

sample 5<smiles>CCCCCCCCC</smiles>

sample 10

FIGURE 5: Example of initial pattern set

OBRÁZEK 5: Př́klad iniciační množiny

LEGEND: sample 1 - Nissan Pivo2

sample 2 - Honda Individual Articulating Commuter sample 3 - Elph by Rizki Tarisa (Indonesia)

sample 4 - Suzuki Pixy

sample 5 - Peugeot MoVille by Woo-Ram Lee (France) sample 6 - Peugeot Moovie by André Costa (Portugal) sample 7 - Renault Twizy

sample 8 - 2028 One by Sergio Luna (Mexico)

sample 9 - GM EN-V

sample 10 - Toyota i-Real
The package, describing the physical conditions for the new design, is shown on the left side of Figure 6. It is represented by a poly-line and graphically specifies a space for passengers, an engine, a trunk etc. The algorithm finds nine principal components of the initial samples, and by setting them to the new values it creates a new curve displayed on the right side of Figure 6 .

Each particular algorithm run can produce a different curve, and a few samples are shown in Figure 7. A human designer has a few computed results and he can select the one which inspires him the most. In simple terms, these results represent the initial samples melted down according to the dimensions of the defined package. We selected one most inspiring result (result 7 in Figure 7) and continued manually with the sketching and designing in 3D software.
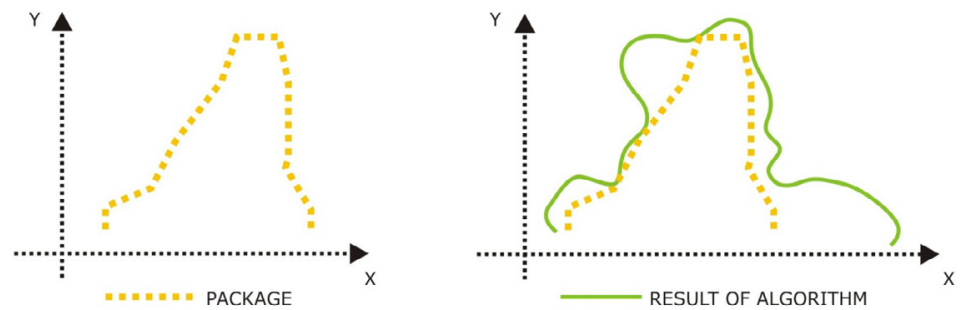

FIGURE 6: Package and newly generated silhoutte

OBRÁZEK 6: Obálka a nově vygenerovaná silueta

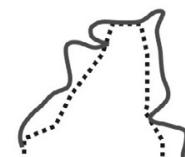

result 1

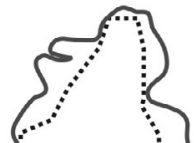

result 4

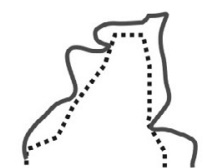

result 2

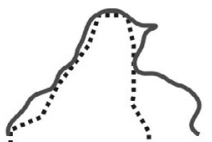

result 5

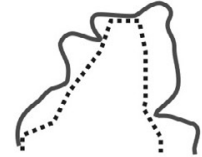

result 3

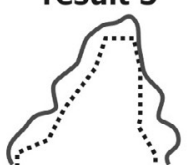

result 6

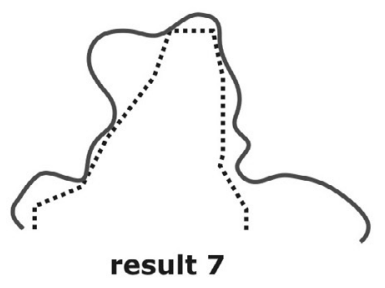

result 7

FIGURE 7: Examples of vehicle silhouttes generated by different algorithms OBRÁZEK 7: Př́iklad siluet vozidel vygenerovaných různými algoritmy 
Figure 8 shows the sketch made on the basis of result 7 with an LCD tablet. Although the curve on the back side runs unexpectedly far from the package, it was also an inspiration for us and we used it for presentation of a trailer concept behind the vehicle.

The next step after making the sketch was to model the vehicle in 3D. Figure 9 shows a visualization of the experimental vehicle for individual urban mobility and it represents the final result of our experiment.

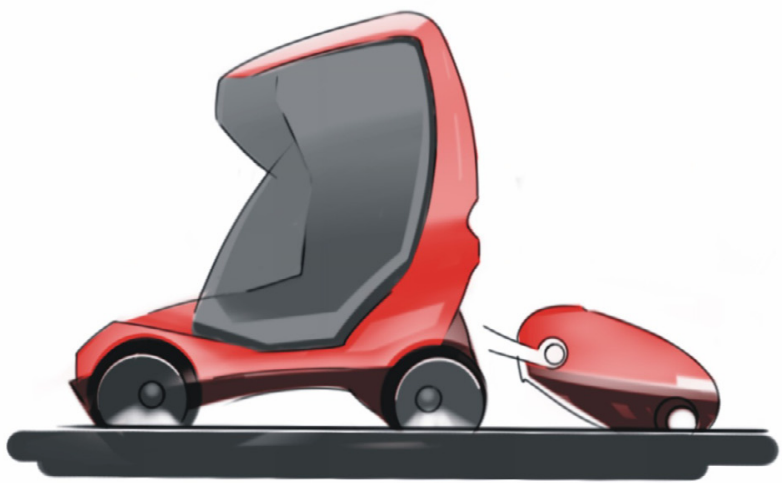

FIGURE 9: Final design - virtual 3D model to scale

OBRÁZEK 9: Výsledný design - virtuální 3D model v měřítku

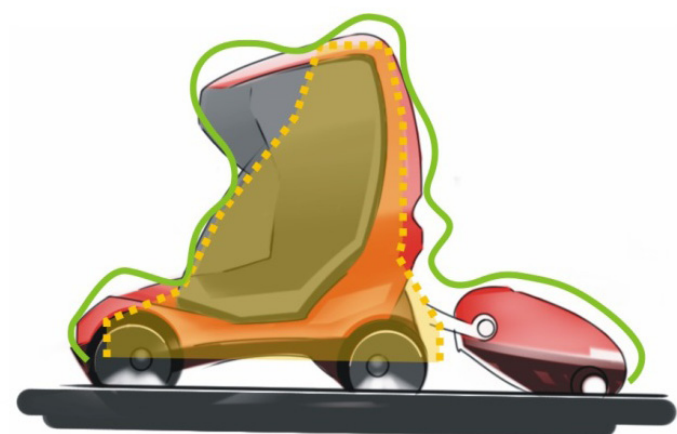

The experiment has three phases described graphically in Figure 11. The first phase translates predecessors' features to the innovative shape. In the second phase we (human designers) choose the most suitable silhouette and create sketches, which are usually at the beginning of the design process. The last part represents an arbitrary kind of finalization; in our case it is the creation of a 3D model.

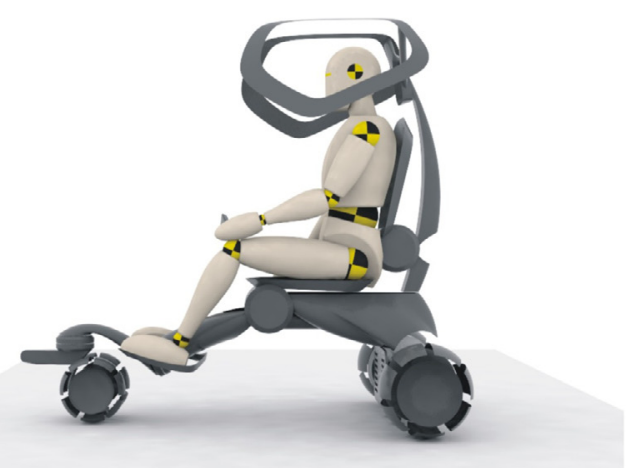

FIGURE 8: Sketch inspired by the algorithm's curve OBRÁZEK 8: Skica inspirovaná produktem algoritmu

FIGURE 10: The left side shows a comparison between the predefined package, automatically generated curve and the created sketch. The right side represents a comparison of the package, the generated curve and the final design.

OBRÁZEK 10: Na levé straně je vidět porovnání mezi předdefinovanou obálkou, automaticky vygenerovanou siluetou a náčrtem vozidla. Na pravé straně obrázku je srovnání obálky, vygenerované siluety a konečným uspořádáním vozidla.

PHASE 1: inspiration

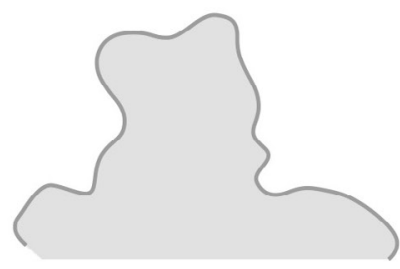

COMPUTER
PHASE 2: ideation

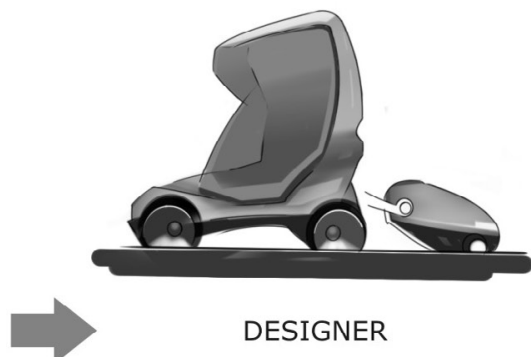

PHASE 3: realization

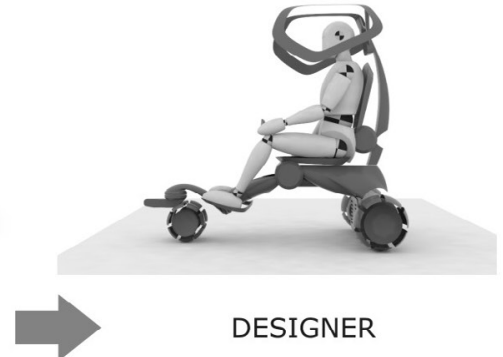

FIGURE 11: Graphical representation of different phases of design process.

OBRÁZEK 11: Grafické znázornění různých fází postupu návrhu.

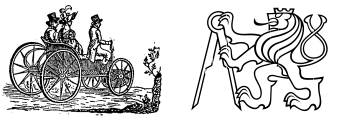




\section{CONCLUSIONS AND FURTHER}

\section{RESEARCH}

This paper deals with the process of evolving a new vehicle design. Our main objective was to answer the question of how exactly to consider inspirations for a new design and obtain useful shapes - vehicle silhouettes that serve as a source inspiration for human designers. The proposed method is part of the creative work and provides original results arising from two main aspects:

1. What is known about the product's look (considering the history and predecessors)

2. What new conditions have to be met (defining a package)

A human designer usually starts with new ideas on a blank sheet of paper. His inspiration comes from the depth of his mind and it makes the development process subconscious. The method we presented in this paper contributes to the process of designing a new product usually handled by a human designer. Using the algorithm leads us through a conscious process to new original silhouettes, which are statistically influenced by the character of their predecessors. The obtained results provide inspiring patterns to help the human designer with innovative design.

Future research will focus on the process of obtaining samples. We envisage having an application with automatic image recognition, where the user just uploads his data (as bitmap images) and the algorithm automatically processes their features and evolves a new vehicle silhouette. Further progress can be made in incorporation of other analyzed features, such as window shapes etc. We have been thinking about 3D applications, but this needs a huge database with accurate data. Since we have developed a method for analyzing a given set of samples, there is still a big challenge to find out how to obtain samples and how to consider the quality and suitability of results.
ACKNOWLED GEMENT

Funding for this research was provided by grantFSI-S-11-30/1454.

\section{REFERENCES}

[1] Alexander Ch. (1964). Notes on the Synthesis of Form. Cambridge (Mass.): Harvard University Press, 216 pages, ISBN 0-674-62751-2

[2] Chin \& Ryan C. C. (2004). Product Grammar: Constructing and Mapping Solution spaces. Massachusetts:

Massachusetts Institute of Technology, 78 pages, Partial Fulfillment of the Requirements for the Degree of Master of Science in Media Arts and Sciences

[3] Johnson R.A. \& Wichern, D. W. (2007). Applied Multivariate Statistical Analysis. Prentice Hall, 800 pages, ISBN-10: 0130925535

[4] Kara L.B., D'Eramo Ch.M. \& Shimada, K. (2006). Pen-based Styling Design of 3D Geometry Using Concept Sketches and Template Models, p. 149-160,

ACM 1-59593-358-1/06/0006

[5] Lin M.C. \& Yan I.H. (2004). Development of a computerassisted procedure for car style design. IJVD, Vol. 35, 2004, p. 289-306, ISSN: 0143-3369

[6] Lin-Lin Ch., Hsien-Chang K. \& Wei-Ken H. (2007). Effects of design features on automobile styling perceptions, IASDR'07 - International Association of Societies of Design Research 2007, Proceedings, Hong Kong, 16 pages

[7] Orsborn S., Cagan J. \& Boatwright P. (2008). Automating the Creation of Shape Grammar Rules. $3^{\text {rd }}$ International Conference on Design Computing and Cognition, p. 3-22, ISBN: 978-1-4020-8727-1

[8] Orsborn S., Cagan, J., Boatwright, P. (2008) Identifying Product Shape Relationships Using Principal Component Analysis. Research in Engineering Design, 184, p. 163-180, ISSN: 0934-9839.

[9] [Orsbor, S., Cagan J. \& Boatwright P. (2009). Quantifying Aesthetic Form Preference in a Utility Function. Journal of Mechanical Design Vol. 13, ISSN: 1050-0472

[10] Stiny G. \& Gips J. (1972). Shape Grammars and the Generative Specification of Painting and Sculpture. Information Processing 71, Amsterdam 1460-1465.

[11] Tumminelli P. (2006). Car Design. teNeues, 400 pages, ISBN-10: 3-8238-4561-6

[12] Yang X.-S. (2008). Nature-Inspired Metaheuristic Algorithm. Luniver Press, 128 pages, ISBN-10: 1905986106 